\title{
$\mathrm{KU}$ 式首長海 綿 骨ラシの試作
}

熊本市民病院整形外科
伊 勢 紘 平・隈 元 一
坂 本 公 宣・赤 崎 幸 二
広 田 耕 三・束 野 通 志
園 田 英 器

\section{A Trial Production of KU Concellous Screw. (Long Neck Type.)}

by

\section{Kouhei Ise, Kazuhito Kumamoto, Kiminori Sakamoto, Kouji Akasaki, Kouzou Hirota, Michishi Tsukano, and Hideki Sonoda}

Kumamoto Municipal Hospital

The cancellous screw (long neck type) is used up to this time with M type and AO type. This type of screw has a haxagonal head so that it is occasionary destroyed when it is pulled out. We made a new type of screw originated from KU Screw. This new screw has a cross-shaped head and a contrary tap. This screw showed a good result in clinical use of arthrodesis or osteosynthesis.

は じめに

首長海綿骨ラシは, 従来, $\mathrm{M}$ 式, $\mathrm{AO}$ 式などの type のものが使用されている。これらのラシは頭部が六角 レンチ式であることや, 逆ダップのないことなどより, 抜釘時に頭部の破損を来したり，あるいは，ドライバ 一の破損など, 多大の労力を費やし，抜釘不能のこと さえ起こることがある。そこでわれわれは, KU 式ラシ の利点である逆タップをつけ，頭部を十字型としたラ シを試作し，基礎実験として，引つ張り試験，曲げ試 験を行い, 臨床的にも, 耐え得るものと考え, 臨床使 用し，満足すべき結果を得たので報告する。

\section{ラシの試作}

試作したラシは $40 \mathrm{~mm}$ より $5 \mathrm{~mm}$ の長さの間隔にて $130 \mathrm{~mm}$ までの 18 種類を作成し, その軸径は $4.5 \mathrm{~mm}$, ねじ山径 $6.5 \mathrm{~mm}$, 谷径は $3.2 \mathrm{~mm}$ となっており, 軸径 $4.5 \mathrm{~mm}$ 以外はM式， $\mathrm{AO}$ 式と同様である(図 1 ). 附属部品としては，とくに新しい器具は用いず, 大
骨ラシ用ドライバー,および Tapping のための Tap を 使用するのみである(図 2 )。

\section{強 度 試 験}

臨床使用に先立ち, 強度試験を行った。これは, 逆 タップを有する本ラシの強度が，逆タップのために， 強度低下を来しては，臨床的に使用出来ないためであ り，簡単ではあるが，本ラシを作成した瑞穂医科工業

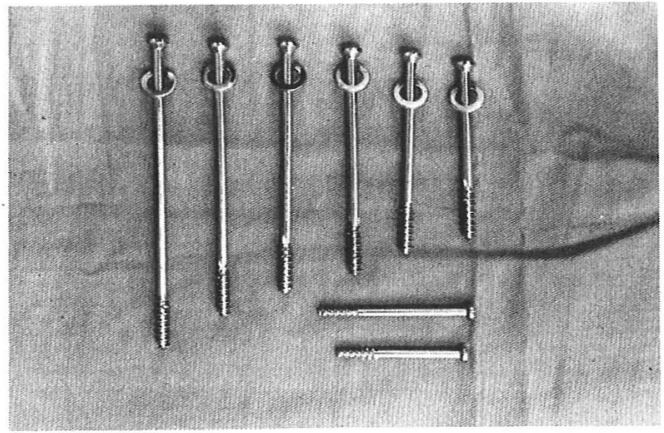

図 1 試作ラシ 
KK，金属材料研究室に依頼し，引っ張り試験，および 曲げ試験を行った。試験は（図 3 ）に示寸方法で行い, 比較材は，(表 1) に示した。

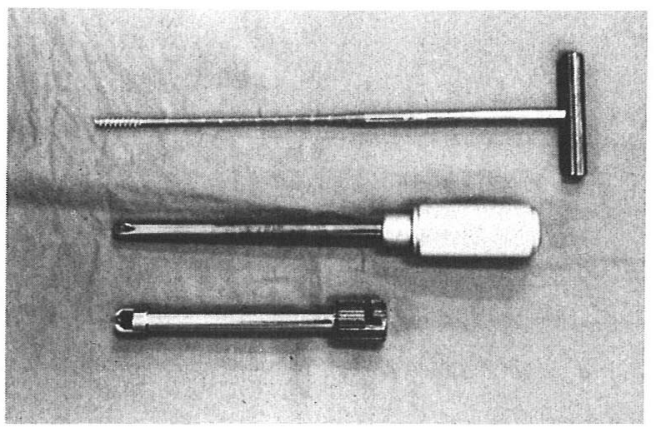

図 2 附属部品

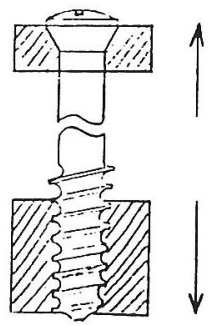

引涱試验

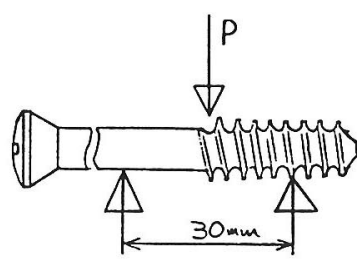

曲リ゙試験

図 3 基礎試験

表 1 試供材

\begin{tabular}{|c|c|c|c|c|c|c|}
\hline $\begin{array}{l}\mathrm{K}-\mathrm{U} \\
\text { 首長海綿骨水じ } \\
\text { 〈比較材〉 }\end{array}$ & 軸径 & $4.5 \mathrm{~mm}$ & & $\begin{array}{l}\text { 山径 } \\
6.5 \mathrm{~mm} \\
6.5 \mathrm{~mm}\end{array}$ & 谷径 & $3.2 \mathrm{~mm}$ \\
\hline M式海綿骨なじ & "1 & $3.5 \mathrm{~mm}$ & n & $6.5 \mathrm{~mm}$ & 11 & $3.2 \mathrm{~mm}$ \\
\hline A O海綿骨水じ & "I & $3.5 \mathrm{~mm}$ & "1 & $6.5 \mathrm{~mm}$ & $n$ & $3.2 \mathrm{~mm}$ \\
\hline ノーススピン $5 \mathrm{~mm}$ & "1 & $3.0 \mathrm{~mm}$ & "1 & $6.0 \mathrm{~mm}$ & "l & $3.0 \mathrm{~mm}$ \\
\hline
\end{tabular}

結

果

引っ張り試験および曲げ試験の結果は（表 2 ）に示 した。引つ張り試験に扔いて, 最大荷重, 強度ともに $\mathrm{M}$ 式海綿骨ラシには劣るものの $\mathrm{AO}$ 式海綿骨ラシとほ ぼ同等の強さを示し，曲げ試験においては，最大荷重， 強度ともにM式, $\mathrm{AO}$ 式には劣るものの, 臨床的には充 分な強度であると考え, 臨床的に使用した。以下，症 例を供覽する。

症例

症例 $1: 41$ 才, 女性, 左変股症.

昭和 59 年 11 月 $\mathrm{KU}$ 式首長海綿骨ラシを使用し, 左 股関節固定術を行い, 術後 2 力月半にて理学療法を開 始し，(図 4) は術後6 力月の X-P 所見である。ゆる み，るいは，たわみもみられていない。

症例 $2: 50$ 才, 女性, 左変股症.

昭和 60 年 2 月に本ラシを使用し, 左股関節固定術を 行い, (図 5 ) は術後 3 力月と 3 週の X-P 所見であり, ゆるみもなく，この時点で股関節装具装着にて，他医 へ転医することの出来た症例である。

症例 $3: 31$ 才, 女性, 右大腿骨骨頭下骨折.

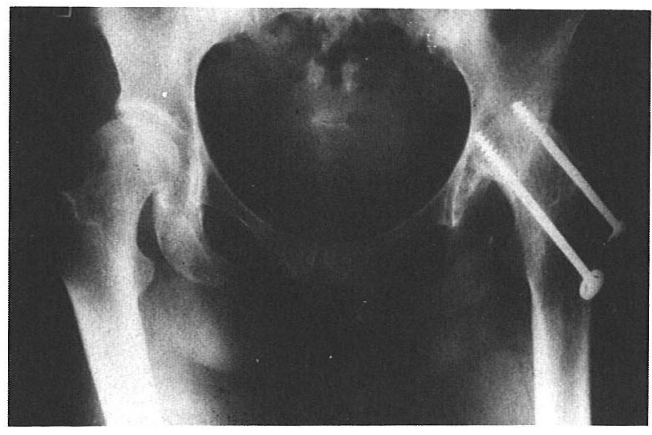

图 4 症例 141 才 女性 左変股症 固定後 6 力月

表 2 結 果

\begin{tabular}{|c|c|c|c|c|}
\hline & \multicolumn{2}{|l|}{ 引 } & \multicolumn{2}{|l|}{ 曲 } \\
\hline & 最大荷重 $(\mathrm{kg})$ & 強度 $\left(\mathrm{kg} / \mathrm{mm}^{2}\right)$ & 最大荷重 $(\mathrm{kg})$ & 強度 $\left(\mathrm{kg} / \mathrm{mm}^{2}\right)$ \\
\hline K-U首長海綿骨水じ & 840 & 104.5 & 114 & 14.2 \\
\hline M式海綿骨ねじ & 1000 & 124.4 & 130 & 16.2 \\
\hline A ○海綿骨ねじ & 850 & 105.7 & 136 & 16.9 \\
\hline $5 \mathrm{~mm}$ ノールスピン & 790 & 111.8 & 80 & 11.3 \\
\hline
\end{tabular}




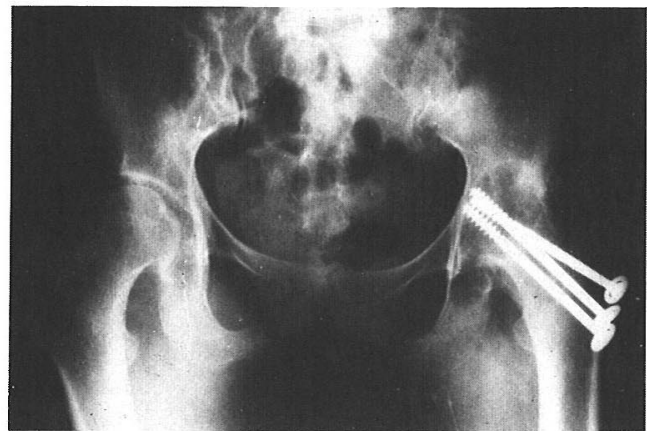

図 5 症例 250 才

女性 左変股症 固定後 3 力月 3 週

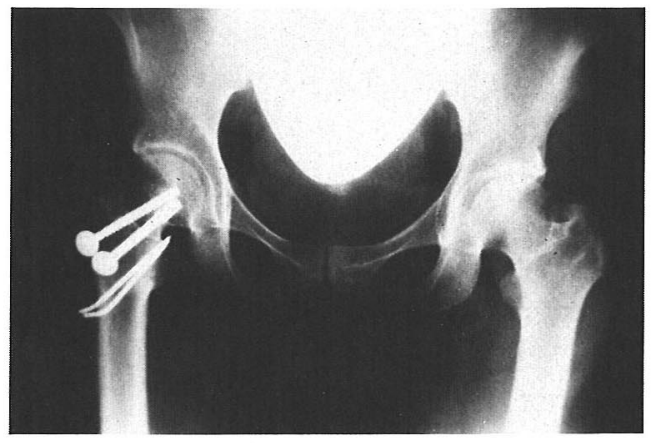

図 6 症例 3 31 女 女性

右大腿骨頸部骨折 術後 3 力月

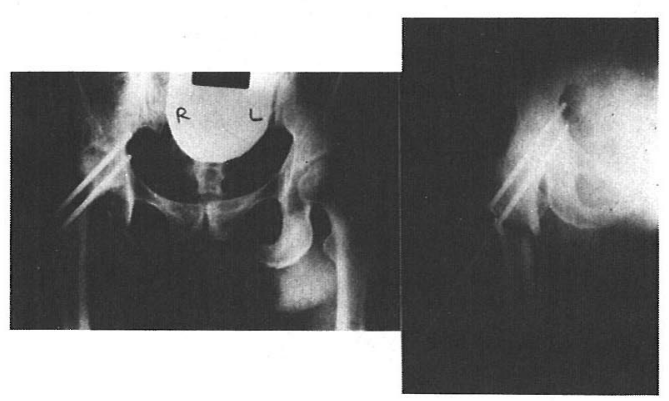

図 7 症例 4 万 才 女性

右変股症，固定後 2 年 2 力月

昭和 57 年 11 月 24 日骨頭下骨折に対し, 観血整復固 定術を本ラシ使用にて施行。転子間にて外反骨切り術 を行った症例である。(図 6 ) は術後 3 カ月目の X-P 所 見である。引きつけもよく，骨癒合も良好である。

症例 $4: 53$ 才, 女性.

昭和 58 年 8 月本ラシを使用し, 右股関節固定術, (図 7 左）施行後，昭和 60 年 12 月に転倒し，(図 7 右）の ような，大腿骨骨折を起こしたものである。この転倒
という衝擊にもかかわらず，本ラシは屈曲，あるいは 折損を起こさず，はからずも，本ラシの強度が証明さ れたものと考えている。

考察

従来首長海綿骨ラシとしてはM式，あるいは $\mathrm{AO}$ 式 が使用されていたが，これらのラシは，抜釘時にその 構造上，非常な労力を要し，抜釘不能に陥ることさえ あった。われわれは，これらのラシの不便さを考え， より容易に抜釘出来，しかも固定力，強度もこれらの ラシに劣らないラシを $\mathrm{KU}$ 式ラシに求めた。 $\mathrm{KU}$ 式ラ シは，KU compression plateに使用するラシとして， 熊本大学整形外科学教室にて開発され ${ }^{11}$ 骨皮質用ラシ と骨海綿質用ラシの 2 種類に分けられる。このうち骨 海綿質用ラシは, 谷径 $3.0 \mathrm{~mm}$, 㸚じ山径 $5.0 \mathrm{~mm}$ であ るが, この谷径を $3.2 \mathrm{~mm}$, ねじ山径を $6.5 \mathrm{~mm}$ とし, 軸径を $4.5 \mathrm{~mm}$ とした首長海綿骨ラシを試作した。こ の軸径 $4.5 \mathrm{~mm}$ は $\mathrm{M}$ 式 $\mathrm{AO}$ 式のものと比較するとこれ らのラシよりも $1 \mathrm{~mm}$ 太くしている。これは, 本ラシ には逆タップがつけられるために, 強度の面での強化 をはかったものである、基礎実験において，M式ある いは $\mathrm{AO}$ 式にやや強度的には劣るものの，臨床的には 充分であると考え使用した。このラシの使用時に，注 意すべきことは,必ずTapによる Tapping をすること によりラシ孔を整え，ドライバーを迴すことのみにて ラシを刺入することが必要である。結果として症例 1 〜4に示したように，充分に固定材料として有用であ り，諸兄の追試をお願いする。

\section{参考 文 献}

1) 玉井達二, 星子 亘：KU Compression Plate〔理 論とその応用了. 熊本, 1960.

\section{質 問長崎大学 伊藤 信之}

曲げ試験の結果について,

この強さは試験物の直径に関係があるので $\phi 4.5 \mathrm{~mm}$

と $\phi 3.5 \mathrm{~mm}$ を比較するのはどうでしょう。

金属の材質はどのようなものですか.

解 答熊本市民病院 伊勢 絋平

なぜ曲げ試験が，弱いのかは不明です。 